\title{
Analisis Hasil Pengukuran Performansi Jaringan 4G LTE 1800 MHz di Area Sokaraja Tengah Kota Purwokerto Menggunakan Genex Asistant Versi 3.18
}

\author{
Ferdinanta Karo Karo ${ }^{1}$, Eka Setia Nugraha ${ }^{2}$, Fikri Nizar Gustiyana ${ }^{3}$ \\ ${ }^{1,2}$ Program Studi S1 Teknik Telekomunikasi, Institut Teknologi Telkom Purwokerto \\ ${ }^{3}$ Program Studi D3 Teknik Telekomunikasi, Institut Teknologi Telkom Purwokerto \\ Jl. D.I Panjaitan No.128 Purwokerto, Indonesia \\ Email : 17101056@ittelkom-pwt.ac.id, ${ }^{2}$ eka_nugraha@ittelkom-pwt.ac.id, \\ 3117201035@ittelkom-pwt.ac.id
}

\begin{abstract}
The implementation of 4G LTE network and its advantages gave us faster speed of mobile network. We need to know the performance of LTE mobile network in Sokaraja Tengah Indonesia, which deployed by Telkomsel network provider by comparing its RSRP, SINR, $R S R Q$, and throughput using drive test method of Genex Probe. Signal performance was measured by drive test dedicated mode on the streamed videos and analyzed with Genex Assistant. The result shows that generally Telkomsel's 4G LTE network in Sokaraja Tengah has $99.7 \%$ of (-70) - (-90) dBm RSRP value, $85.09 \%$ of 1-15 SINR value, 99.23\% of (-15)$0 \mathrm{dBm}$ RSRQ value, average uplink $2575 \mathrm{kbps}$ and downlink $1530 \mathrm{kbps}$ of throughput.
\end{abstract}

Keywords: LTE, Drive Test, RSRP, SINR, RSRQ, Throughput

\begin{abstract}
Abstrak
Lahirnya Teknologi 4G LTE dengan segala kelebihan yang di janjikan dibanding dengan teknologi sebelumnya telah membawa kita ke era komunikasi data perangkat bergerak yang super cepat. Untuk mengetahui seberapa besar perkembangan teknologi LTE saat ini. Maka, dilakukanlah penelitian terhadap performansi mobile internet di wilayah sokaraja tengah Yaitu dengan cara membandingkan RSRP, SINR, RSRQ dan Troughput dengan KPI Teori dan KPI Telkomsel Tujuan yang ingin dicapai dalam penelitian ini adalah untuk mengetahui performansi sinyal 4G LTE operator Telkomsel dengan metode drive test menggunakan aplikasi Genex Probe di area Sokaraja Tengah, Purwokerto, Jawa Tengah. Performansi sinyal 4G LTE diukur dengan drive test Dedicated Mode, dengan membuat sebuah Test Plan pengguna melakukan Streaming video. kemudian hasil dari drive test dianalisis menggunakan foftware genex asistant. Hasil dari analisis kualitas kekuatan sinyal 4G LTE secara keseluruhan menunjukkan kualitas provider Telkomsel di area Sokaraja tengah, Purwokerto memiliki performansi jaringan 4G LTE yang bagus dengan nilai lebih dari $90 \%$ hasil pengukuran berada di rentang nilai $0-(-90)(\mathrm{dBm})$, nilai SINR normal lebih dari $85 \%$ hasil pengukuran berada di rentang $1-15(\mathrm{~dB})$, dan nilai dari RSRQ memiliki performasi yang bagus dengan persentase $99 \%$ berada pada rentang bagus dan mendapatkan rata- rata Troughput Uplink 2575 Kbps dan Downlink 1530 Kbps
\end{abstract}

Kata kunci: LTE, Drive Test, RSRP, SINR, RSRQ, Throughput 


\section{Pendahuluan}

Kebutuhan masyarakat Indonesia akan informasi dan komunikasi terus berkembang pesat dari waktu ke waktu. Menyebabkan penyedia jasa layanan telekomunikasi seluler dituntut untuk berkembang guna memenuhi keragaman kebutuhan konsumennya. Salah satu yang terlihat sangat berkembang adalah kebutuhan akan komunikasi paket data[1].

Teknologi komunikasi LTE hadir sebagai solusi atas kebutuhan akan komunikasi data yang semakin meningkat. Teknologi standar yang diterapkan oleh 3 gpp pada ralease 8. Standar tersebut meliputi: Kecepatan maksimal data downlink yang mencapai 100 Mbps saat pengguna bergerak cepat dan 1 Gbps saat diam[2].

Teknologi telekomunikasi seluler yang akan diteliti adalah 4G LTE, akan tetapi teknologi 4G LTE tetap memiliki permasalahan yang dikeluhkan pelanggan, permasalahan tersebut diantaranya yaitu sinyal yang diterima tidak stabil, akses data yang susah tersambung, dan kegagalan koneksi, maka dari itu akan dilakukan penelitian supaya mengetahui nilai beberapa parameter pada jaringan 4G LTE seperti RSRP (Reference Signal Receive Power), SINR (Signal Interference to Noise Ratio), PCI (Physical Cell Identity), dan Troughtput. [3].Maka dari itu peneliti mencoba mengetahui kualitas jaringan 4G LTE operator Telkomsel di frekuensi $1800 \mathrm{MHz}$ di area Sokaraja Tengah, Purwokerto, Jawa Tengah.

Diharapkan dengan penelitian kualitas jaringan 4G LTE di area Sokaraja Tengah, Purwokerto, Jawa Tengah ini, operator telekomunikasi dapat mengoptimalkan layanan dalam jaringan telekomunikasi sehingga permasalahan seperti sinyal yang diterima tidak stabil, akses data yang susah tersambung, dan kegagalan koneksi dalam jaringan dapat teratasi. [2].

\section{Tinjauan Pustaka}

Long Term Evolution (LTE) adalah sebuah nama yang diberikan kepada suatu proyek dalam The Third Generation Partnership Project (3GPP) yang diciptakan untuk mengembangkan teknologi Universal Mobile Telecomunication System (UMTS) dalam mengatasi kebutuhan data mendatang. Menurut Standar, LTE memberikan kecepatan downlink 100 Mbps. LTE akan membawa banyak manfaat pada perkembangann jaringan selular

Selain itu, teknologi LTE ini juga memiliki Arsitektur Internet protokol (IP) yang memungkinkan kecepatan akses yang lebih cepat dari pada arsitektur CircuitSwitching yang di gunakan pada generasi sebelumnya.

Seperti pada generasi - generasi sebelumnya kecepatan data pada teknologi LTE ini juga bisa di pengaruhi oleh banyak faktor, yaitu faktor internal seperti 
bandwidth, dan kekuatan sinyal. Dan faktor eksternal seperti UE (User Equipment), Geografis dan cuaca.3GPP LTE (Long Term Evolution) adalah nama yang diberikan untuk standar teknologi komunikasi baru yang berkembang oleh 3GPP untuk mengatasi peningkatan permintaan kebutuhan akan layanan komunikasi. LTE juga merupakan lanjutan dari evolusi $2 \mathrm{G}$ dan $3 \mathrm{G}$ sistem dan juga untuk menyediakan layanan tingkat kualitas yang sama dengan jaringan wired. Kemampuan dan keunggulan dari LTE (Long Term Evolution) terhadap teknologi sebelumnya selain dari kecepatan dalam transfer data tetapi karena LTE (Long Term Evolution) dapat memberikan coverage dan kapasitas layanan yang lebih besar, mengurangi biaya dalam operasional, mendukung penggunaan multipleanntena, fleksibel dalam penggunaan bandwidth operasi dan juga dapat terhubung atau terintegrasi dengan teknologi yang sudah ada [4].

Arsitektur jaringan LTE jika kita lihat sebenarnya cukup sederhana seperti dengan teknologi jaringan yang telah ada sebelumnya. Seperti pada gambar 1 . Keseluruhan arsitektur LTE terdiri dari beberapa eNodeB yang menyediakan akses dari UE ke E-Utran [4].

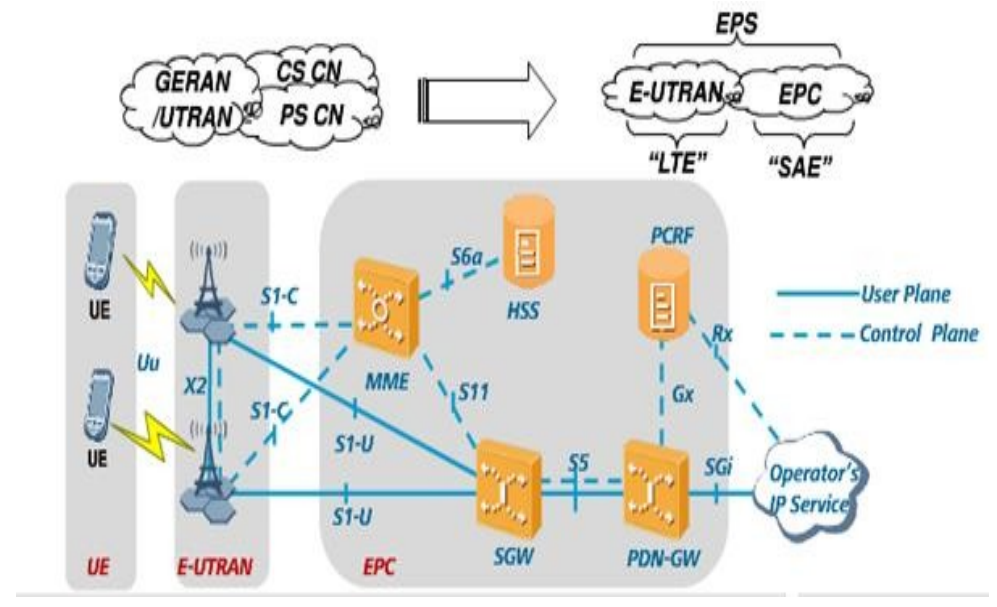

Gambar 1 Arsitektur 4G LTE

Parameter Quality of Services KPI yang ada pada teknologi LTE terdiri atas 4 macam yaitu sebagai berikut [5]:

a. Accesbility

Kemampuan user mengakses jaringan untuk menginisiasi komunikasi. Contoh pada jaringan 4G LTE yang termasuk dalam kategori Accessibility adalah ERAB Success Rate(\%), LTE RRC Setup Success(\%), Call Setup Success Rate(\%), LTE Attach Success Rate(\%), Services Request (EPS) Success Rate(\%).

\section{b. Retainability}


Bagaimana menjaga jaringan pada performansi bagus. Contoh pada jaringan LTE yang termasuk dalam kategori retainability adalah: Services Drop Rate(\%).

c. Mobility

Bagaimana pengguna dapat bergerak dengan mudah dari suatu tempat ke tempat lain tanpa terjadi pemutusan hubungan. Contoh pada jaringan LTE yang termasuk dalam kategori Mobility adalah Intra Freq HO Attemp Success Rate(\%), Intra Freq HO Success Rate(\%), dan lain-lain.

\section{d. Integrity}

Bagaimana trafik besar di dalam jaringan, Contoh pada jaringan LTE yang termasuk dalam kategori integrity adalah sebagai berikut, MAC Troughput UL dan DL Avg (Kbit/s) dll

Drive test merupakan salah satu bagian pekerjaan dalam optimalisasi jaringan radio. Drive test bertujuan untuk mengumpulkan informasi jaringan secara real di lapangan [4]. .Data pengukuran dari area yang dinginkan dikumpulkan menggunakan software khusus dimana Engineer mendapatkan RF coverage atau mengidentifikasi permasalahan yang terjadi pada lapangan serta menentukan pemecahan masalah tersebut.

Parameter yang digunakan dalam drive test pada teknologi LTE adalah

a. RSRP (Reference Signal Received Power)

RSRP LTE power yang diterima oleh user dalam frekuensi tertentu, semakin jauh jarak antara site dan user, maka semakin kecil pula RSRP yang diterima oleh user. RS merupakan Reference Signal atau RSRP di tiap titik jangkauan coverage. User yang berada di luar jangkauan maka tidak akan mendapatkan layanan LTE [6].

Tabel 1 Standar Nilai RSRP Operator telkomsel

\begin{tabular}{ll}
\hline Kategori & Batas Nilai RSRP (dBm) \\
\hline Bagus & $(-70)-(-90)$ \\
Normal & $(-91)-(-110)$ \\
Buruk & $(-111)-(-130)$ \\
\hline
\end{tabular}

b. SINR (Signal Interference to Noise Ratio)

SINR merupakan rasio perbandingan kuat sinyal antara sinyal utama yang dipancarkan dengan interferensi dibanding noise background yang timbul (tercampur dengan sinyal utama). Dalam arti rasio yang antara rata-rata power diterima dengan rata-rata interferensi dan noise. Minimum RSRP dan SINR yang sesuai tergantung dengan bandwidth frekuensinya [6] 
Tabel 2. Standar Nilai SINR Operator Telkomsel

\begin{tabular}{ll}
\hline Kategori & Batas Nilai SINR (dB) \\
\hline Bagus & $16->30$ \\
Normal & $1-15$ \\
Buruk & $<-10-0$ \\
\hline
\end{tabular}

c. RSRQ (Reference Signal Received Quality)

RSRQ merupakan parameter yang menentukan kualitas dari sinyal yang diterima. RSRQ membantu sistem dalam proses handover di mana RSRQ dapat meranking performansi kandidat sel dalam proses cell selection reselection dan handover berdasarkan kualitas sinyal yang diterima.

Tabel 3. Standar Nilai RSRQ Operator telkomsel

\begin{tabular}{cc}
\hline $\mathbf{( d B m})$ Range & Kategori RSRQ \\
\hline$-15-0$ & Good \\
$-20-(16)$ & Fair \\
$-30-(-21)$ & Poor \\
\hline
\end{tabular}

d. Throughput

Throughput pada drivetest LTE adalah nilai Kecepatan data (Kbit/s) dari UE ke EnodeB, Kita dapat menghitung 2 tipe Throughput yaitu Download dan Upload[5]. Akan tetapi, Untuk menyesuaikan dengan kebutuhan masyarakat biasanya kegiatan drive test dilakukan dengan menggunakan metode download[5].

\section{Metode Penelitian}

Penelitian dilaksanakan di area Sokaraja Tengah, Purwokerto, Jawa Tengah. Peralatan yang digunakan dalam penelitian ini adalah:

1. Software Genex Probe versi 3.18 untuk Drive Test

2. GPS (Global Pointing System) BU - 353 untuk menentukan posisi pada saat Drive Test

3. Laptop sebagai alat untuk memonitoring pengukuran

4. Modem Huwawei E398 sebagai koneksi dari Base Station ke Laptop

5. Software Genex Assistant versi 3.18 untuk Drive Test 


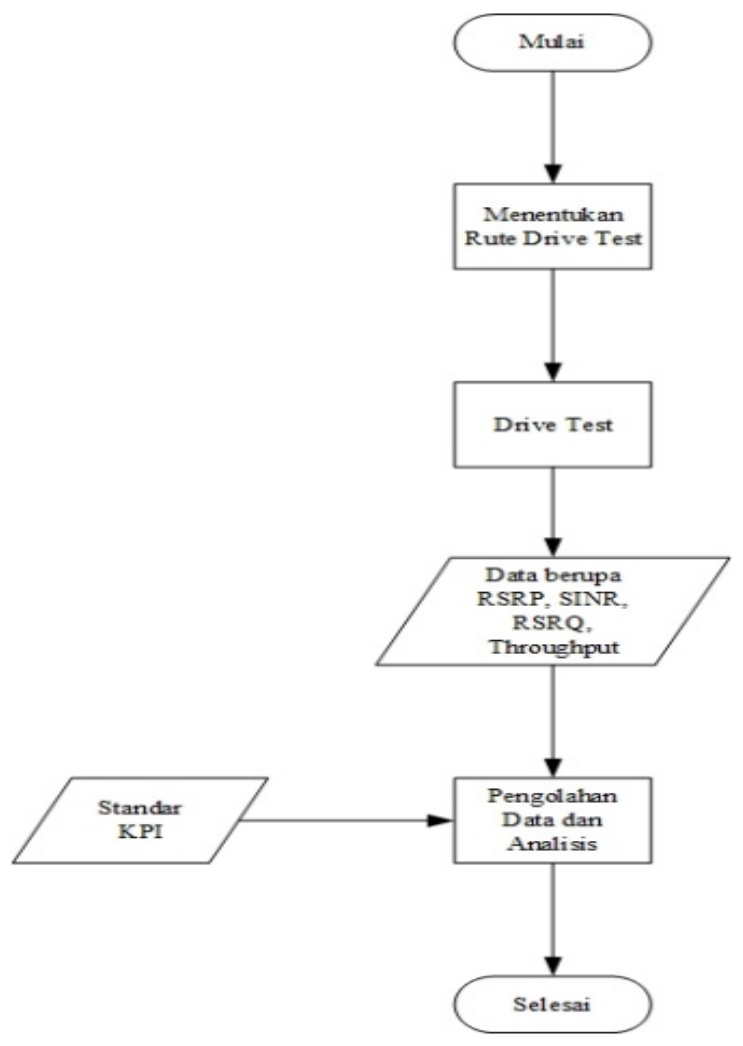

Gambar 2 Flowchart Alur pengambilan data

Pengukuran performansi jaringan LTE diukur dengan drive test Dedicated Mode dengan membuat sebuah Test plan Streaming Video.

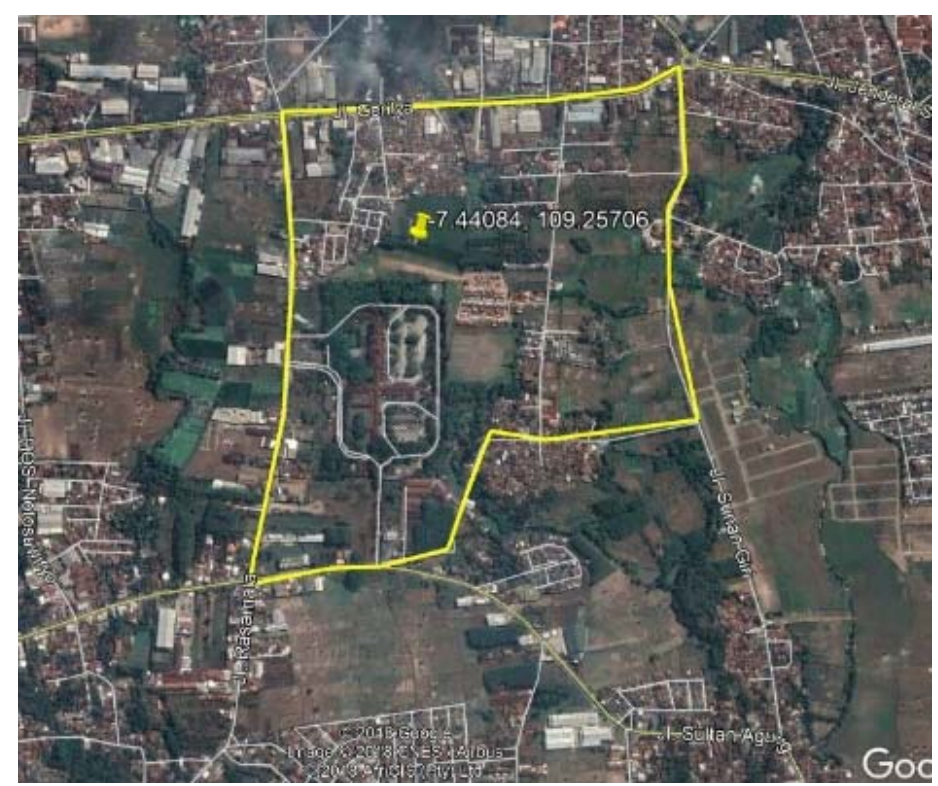

Gambar 3 Rute pengukuran 
AITI: Jurnal Teknologi Informasi

Volume 16 No. 2 Agustus 2019, 116-124

\section{Hasil dan Pembahasan}

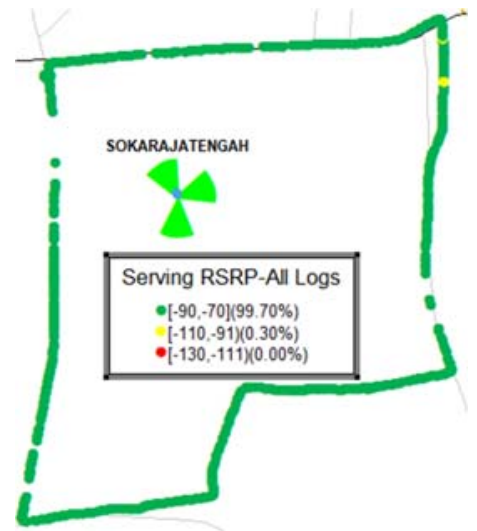

Gambar 4 RSRP area Sokaraja Tengah, Purwokerto

Tabel 4 Hasil Pengukuran RSRP Operator telkomsel

\begin{tabular}{cc}
\hline Batas Nilai RSRP (dBm) & Persentase (\%) \\
\hline$(-70)-(-90)$ & 99,70 \\
$(-91)-(-110)$ & 0.30 \\
$(-111)-(-130)$ & 0,0 \\
\hline
\end{tabular}

Tabel 4 menunjukkan kualitas RSRP pada eNodeB Sokaraja Tengah dengan persentase 99,70\% hasilnya berada pada rentang baik,dari hal ini dapat disimpulkan bahwa RSRP pada area sokaraja tengah baik .rentang normal dan buruk persentase di bawah $0 \%$.

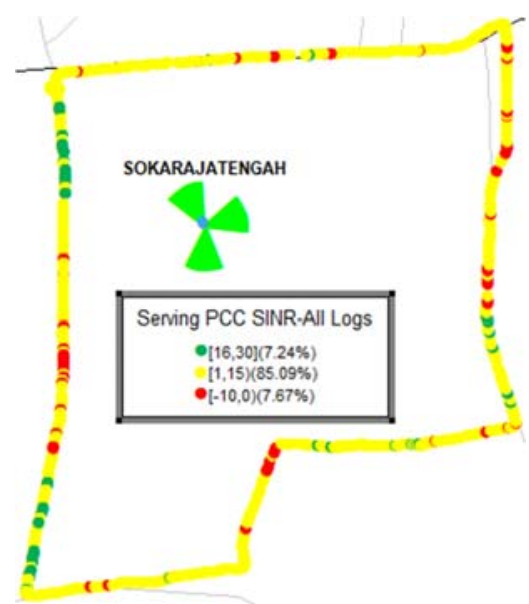

Gambar 5 SINR area Sokaraja Tengah, Purwokerto 
Tabel 5 Hasil Pengukuran SINR Operator Telkomsel

\begin{tabular}{cc}
\hline Batas Nilai RSRQ(dBm) & Persentase (\%) \\
\hline $16->30$ & 7,24 \\
$1-15$ & 85,09 \\
$<-10-0$ & 7,67 \\
\hline
\end{tabular}

Tabel 5 menunjukkan kualitas SINR pada eNodeB Sokaraja Tengah dengan persentase $7,24 \%$ hasilnya berada pada rentang baik,dan $85,09 \%$ berada pada rentang normal.persentase rentang buruk $7,67 \%$ dari hal ini dapat disimpulkan bahwa dibutuhkan perbaikan untuk meningkatkan nilai SINR agar nilai atau persentase semakin baik.

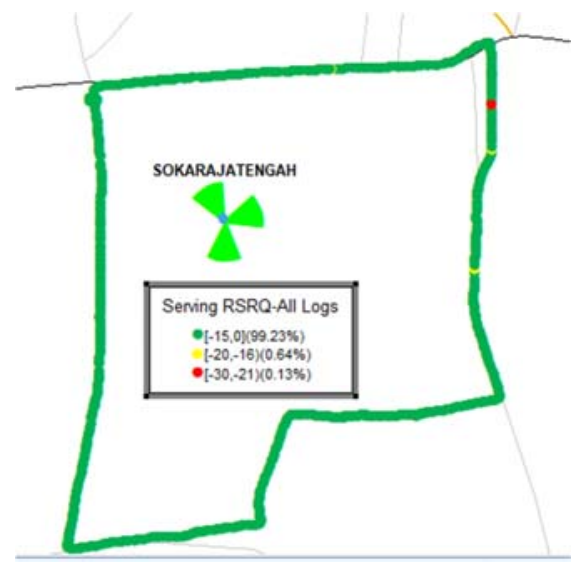

Gambar 6 RSRQ area Sokaraja Tengah, Purwokerto

Tabel 6. Hasil Pengukuran SINR Operator Telkomsel

\begin{tabular}{cc}
\hline Batas Nilai RSRP $\mathbf{( d B m )}$ & Persentase (\%) \\
\hline$-15-0$ & 99,23 \\
$-20-(16)$ & 0.64 \\
$-30-21$ & 0,13 \\
\hline
\end{tabular}

Tabel 6 menunjukkan kualitas RSRQ pada $e N o d e B$ sokarajatengah dengan persentase $99,23 \%$ hasilnya berada pada rentang baik. Dari hal ini dapat disimpulkan bahwa RSRQ pada area Sokaraja Tengah baik. Rentang normal dan buruk persentase di bawah $0 \%$.

Hasil Drive Test di area Sokaraja Tengah, Purwokerto dapat diketahui bahwa User di layani oleh beberapa Cell yaitu dengan PCI 343, 342, 344, 175, 353, $351,111,28$, dan 29 dan mendapatkan rata- rata Troughput Uplink 2575 kbps dan Downlink 1530 kbps. 
AITI: Jurnal Teknologi Informasi

\begin{tabular}{|l|l|}
\hline \multicolumn{2}{|l|}{ PCC PHY Throughput UL_All Logs } \\
\hline Element & \\
\hline Average & PCC PHY Throughput UL_All Logs \\
CDF $5 \%$ & 2570.69 \\
Maximum & 904.00 \\
Minimum & 18336.00 \\
Standard Deviation & 56.00 \\
{$[0,500)$} & 2828.69 \\
{$[500,1000)$} & $5(0.98 \%)$ \\
{$[1000,5000)$} & $193(37.77 \%)$ \\
{$[5000,10000)$} & $241(47.16 \%)$ \\
{$[10000,307200]$} & $57(11.15 \%)$ \\
Sum Total & $15(2.94 \%)$ \\
& 511 \\
\hline
\end{tabular}

Gambar 7 Throughput uplink

\begin{tabular}{l|l}
\hline Element & PCC PHY Throughput DL_All Logs \\
\hline Average & 1520.19 \\
\hline CDF $5 \%$ & 80.00 \\
Maximum & 30503.00 \\
Minimum & 80.00 \\
Standard Deviation & 4223.44 \\
{$[0,500)$} & $360(67.16 \%)$ \\
{$[500,1000)$} & $89(16.60 \%)$ \\
{$[1000,5000)$} & $46(8.58 \%)$ \\
{$[5000,10240)$} & $14(2.61 \%)$ \\
{$[10240,153600)$} & $27(5.04 \%)$ \\
{$[153600,307200)$} & $0(0.00 \%)$ \\
{$[307200,460800)$} & $0(0.00 \%)$ \\
{$[460800,614400)$} & $0(0.00 \%)$ \\
{$[614400,768000)$} & $0(0.00 \%)$ \\
{$[768000,1024000]$} & $0(0.00 \%)$ \\
Sum Total & 536
\end{tabular}

Gambar 8 Throughput downlink

\section{Simpulan}

Dari penelitian yang telah dilakukan dapat diambil beberapa kesimpulan yatu:

a. Kekuatan sinyal jaringan Telkomsel 4G LTE di area Sokaraja Tengah, Purwokerto , Jawa Tengah memiliki kualitas yang bagus.

b. Rata - rata Troughput jaringan 4G LTE operator Telkomsel di Sokaraja tengah, Purwokerto, Jawa Tengah untuk Uplink adalah 2575 Kbps dan Downlink 1530 Kbps.

c. User di area rute yang dilakukan Drive Test dilayani oleh beberapa Cell yaitu Cell dengan PCI 343, 342, 344, 175, 353, 351, 111, 28, dan 29. 


\section{Daftar Pustaka}

[1] D. Suyuti, "Studi Perkembangan LTE dan Wimax di Indonesia.," J. Ilm. Elektr. Enj. UNHAS, vol. Vol.09, no, 2011.

[2] M. Prasetia, "Mekanisme carrier Aggregation pada Jaringan 4G LTE- Advanced.," Univ. Negeri Lampung, 2016.

[3] T. Wulansari, “'Analisis Kualitas Kekuatan Sinyal 4g Lte Dengan Menggunakan Metode Drive Test," "Univ. Tidar, Magelang, 2018.

[4] I. P. A. V.S Kusumo, P.K. Sudiarta, "Analisis Performansi dan Optimalisasi Layanan LTE Telkomsel di Denpasar Bali," E-Journal Spektrum Vol.2, no. 3, vol. Vol.2, no., 2015.

[5] D. Wardhana, 4G Handbook Edisi Bahasa Indonesia. Jakarta: Nulis Buku, 2014.

[6] V. D. Ramadianty, “'Analisis Pengukuran Performansi Jaringan 4g Lte Telkomsel Dalam Event Game Mobile Legends: Bang-Bang Di Pontianak," Univ. Tanjungpura, Pontianak, 2018. 